\title{
Keputusan Pemilihan Strategi Manajemen Laba pada Perusahaan Manufaktur yang Mengalami Financial Distress di Indonesia
}

\author{
Putu Ery Setiawan ${ }^{1}$ \\ I Made Pande Dwiana Putra ${ }^{2}$ \\ ${ }^{1,2}$ Fakultas Ekonomi dan Bisnis, Universitas Udayana, Indonesia \\ email: erys.adel@yahoo.com.au
}

DOI: https://doi.org/10.24843/JIAB.2019.v14.i02.p05

\section{Jurnal Ilmiah Akuntansi dan Bisnis (JIAB)}

https://ojs.unud.ac.id/index.php/jiab/ user/profile

Volume 14

Nomor 2

Juli 2019

Halaman 196-207

p-ISSN 2302-514X

e-ISSN 2303-1018

\section{INFORMASI ARTIKEL}

Tanggal masuk:

16April 2019

Tanggal revisi:

21 Mei 2019

Tanggal terima:

01 Juli 2019

\section{ABSTRAK}

Penelitian ini membahas real earnings management dan classification shifting beserta dengan accrual earnings managemet sebagai alternatif strategi pada perusahaan yang mengalami financial distress, dan perbedaan pilihan strategi pada tiap tahapan financial distress. Penelitian ini dilakukan pada seluruh perusahaan manufaktur yang terdaftar di BEI selama enam tahun dari 2012 sampai 2017 yang mengalami financial distress. Sampel ditentukan dengan purposive sampling yakni perusahaan emiten BEI sektor manufaktur yang mengalami financial distress pada periode sebanyak 43 perusahaan dengan keseluruhan 258 data amatan. Teknik analisis data yang digunakan adalah analisis regresi linier majemuk dengan bantuan software SPSS. Hasil penelitian ini menunjukkan bahwa pada tahap awal financial distress perusahaan cenderung memilih strategi real earnings management yang berupa penurunan produksi dan classification shifting. Sementara pada tahap lanjut strategi yang menjadi pilihan adalah real earnings management melalui penurunan biaya selling, general and administrative. Akhirnyapada tahap ekstrim, perusahaan cenderung melakukan income-decreasing accruals management.

Kata kunci: Financial distress, accrual earnings managemet, real earnings management, classification shifting

\section{Decision on the Selection of Earnings Management Strategy in Financially-Distressed Manufacturing Companies in Indonesia}

\section{ABSTRACT}

This study discusses real earnings management and classification shifting along with accrual earnings management as an alternative strategy for companies that experience financial distress, and differences in choices of strategies at each stage of financial distress. This research was conducted on all manufacturing companies which experienced financial distress among those listed on the Indonesian Stock Exchange for six years from 2012 to 2017. Purposive sampling was used to collect data from all the manufacturing sector companies listed on the IDX that experienced financial distress. The sample companies totaled to 43 with a total of 258 observation data. The multiple linear regression technique was used in data analysis, analysis aided by SPSS. The results of this study indicate that in the early stages of financial distress, companies tend to choose the real earnings management strategy in the form of decreased production and classification shifting. While in the later stages the chosen strategy is real earnings management through a reduction in selling, general and administrative expenses. Finally at extreme stage, companies tend to adopt income-decreasing accruals strategies Keywords: Financial distress, accrual earnings management, real earnings management, classification shifting 


\section{PENDAHULUAN}

Manajer sering kali memilih pendekatan strategi yang dapat secara instan menunjukkan perbaikan kinerja, meskipun tersedia pilihan strategi yang dapat bermanfaat bagi perusahaan dalam jangka panjang. Ketakutan akan pelanggaran kontrak utang (debt covenant) dan kehilangan pekerjaan serta motifmotif personal lainnya mendorong manajer untuk melakukan manajemen laba guna menutupi keadaan sebenarnya. Manajer terdorong untuk melakukan manajemen laba dan cash flow pada saat menghadapi financial distress. Motivasi di balik praktek ini antara lain untuk memperoleh pinjaman tambahan atau mengurangi kemungkinan kebangkrutan, akuisisi atau takeover di samping untuk menghindari pelanggaran kontrak utang dan mempertahankan pekerjaannya (Nagar \& Sen, 2016).

Kasus manajemen laba yang relatif baru terjadi pada Toshiba di Jepang tahun 2015 dimana direksi telah berperan aktif dalam meningkatkan laba usaha Toshiba sebesar Rp 15,85 Triliun sejak tahun 2008. Ketika isu akuntansi ini terungkap, harga saham Toshiba menurun hingga 20 persen (Simbolon, 2015). Kasus manajemen laba di Indonesia yang menjurus pada fraud terjadi pada PT. Kimia Farma, Tbk. yang melakukan peningkatan (mark up) laporan keuangan (Dewi \& Latrini, 2016).

Indonesia termasuk dalam kelompok negara dengan perlindungan investor yang lemah. Indonesia berada pada tingkat pertama yang mempraktikkan manajemen laba yang paling besar jika dibandingkan dengan Malaysia, Filipina, dan Thailand (Dewi \& Latrini, 2016). Kasus manajemen laba yang terjadi menyebabkan menurunnya kepercayaan investor terhadap perusahaan. Manajer melakukan manajemen laba salah satunya sebagai strategi dalam menghadapi financial distress. García et al. (2009) dan Zang (2012) telah melakukan penelitian yang mengaitkan financial distress terutama kebangkrutan dengan strategi manajemen laba. Namun penelitian-penelitian tersebut belum menganalisis pilihan strategi pada masing-masing tahapan financial distress. Penelitian seperti ini belum pernah dilakukan Di Indonesia. Penelitian lebih banyak hanya melihat strategi manajemen laba sebagai accrual earnings management (AM) dan belum ada yang memperhitungkan strategi real earnings management (RM) dan classification shifting (CS) sebagai komponen-komponen strategi manajemen laba. Berdasarkan uraian di atas, maka permasalahan dalam penelitian ini adalah strategi-strategi manajemen laba, apa yang diterapkan perusahaan pada tahap-tahap awal financial distress, tahaptahap lanjutan financial distress dan pada tahaptahap ekstrim financial distress (menjelang kebangkrutan).

Perilaku manajer pada saat perusahaan mengalami financial distress menarik untuk diamati karena para manajer dihadapkan pada pilihan antara keberlangsungan perusahaan dalam jangka panjang dengan insentif jangka pendek seperti pendanaan dan kepentingan pribadi. Studi mengenai financial distress sebelumnya kebanyakan berfokus pada salah satu tahapan financial distress saja, apakah tahap awal atau tahap ekstrim (kebangkrutan). Penelitian ini mencoba melihat seluruh tahapantahapan financial distress guna melihat perbandingan strategi manajemen laba yang dipilih manajer sesuai dengan kondisi yang dihadapi pada masing-masing tahapan.

Penelitian terdahulu juga relatif belum banyak membahas tentang strategi manajemen laba secara riil (real earnings management/RD), misalkan pemotongan biaya-biaya discretionary seperti biaya riset (research and development/R\&D) dan biaya penjualan, administrasi dan umum (selling, general and administrative/SGA), serta perubahan tingkat produksi untuk memanipulasi laba. Pendekatan lain yang belum juga banyak diteliti adalah strategi classification shifting (CS) dalam laporan laba rugi dimana laba operasi ditingkatkan dengan menggeser biaya operasi atau harga pokok ke dalam kategori special items dan discontinued operations. Penelitian ini akan membahas real earnings management dan classification shifting beserta dengan accrual earnings management sebagai alternatif strategi pada perusahaan yang mengalami financial distress, dan perbedaan pilihan strategi pada tiap tahapan financial distress.

Penelitian terkini mengenai financial distress perlu memperhitungkan semua pilihan strategi yang tersedia bagi manajemen. Bila hanya berfokus pada strategi akrual saja, dikhawatirkan tidak akan diperoleh pemahaman secara komprehensif atau bahkan bias. Pemilihan satu strategi seringkali berkaitan dengan strategi lainnya, apakah saling melengkapi ataukah saling menggantikan. Penelitian ini diharapkan dapat menginspirasi penelitian serupa di masa depan, terutama di Indonesia, untuk mencakup ketiga strategi manajemen laba yang tersedia bagi manajer pada saat financial distress. Manajemen dapat memilih strategi atau kombinasi 
beberapa strategi terbaik yang menghasilkan dampak optimal dengan memperhatikan kondisi yang ada baik dalam jangka pendek maupun jangka panjang. Manajemen dapat memperoleh manfaat dari penelitian ini dari sisi alternatif yang tersedia pada saat perusahaan mengalami financial distress tanpa harus melakukan fraud atau manipulasi, serta dapat menambah wawasan mengenai praktik manajemen laba yang umum dilakukan pelaku industri. Manajemen pun dapat menilai praktik-praktik manajemen laba mana yang bisa dilakukan dan mana yang tidak dengan memperhatikan ketentuan standar akuntansi, hukum dan peraturan perundangan, serta etika bisnis.

Dewasa ini tingginya persaingan bisnis dan dunia kerja telah mendorong menjamurnya berbagai praktik yang dulunya relatif terbatas dan bahkan tabu, seperti manajemen laba. Meski ada pihak-pihak yang diuntungkan oleh praktik-praktik tersebut, banyak pula pihak yang dirugikan, seperti misalnya kreditor dan investor. Para investor dan kreditor dituntut untuk tidak menerima mentah-mentah informasi laba yang disajikan. Mana laba yang kredibel, mana laba yang telah terdistorsi oleh manajemen laba. Manajemen laba dapat mengakibatkan kesalahan investor dalam pengambilan keputusan karena didasarkan pada informasi laba yang salah. Penelitian berusaha memberikan penjelasan sehingga investor dapat menganalisis lebih jauh informasi keuangan perusahaan dengan memperhitungkan strategi manajemen laba yang diterapkan manajemen perusahaan.

Perusahaan dikatakan mengalami financial distress apabila menghadapi kesulitan melunasi utang dan kewajiban lainnya. Literatur yang ada menggunakan berbagai proksi untuk mengukur distress. Proksi yang lebih mudah dihitung adalah debt to equity ratio (DER), namun DER yang tinggi sering kali tidak serta merta terkait dengan keadaan financial distress (Dechow et al. 2010). Proksi financial distress yang paling banyak digunakan barangkali adalah Altman's Z-Score, termasuk penelitian-penelitian terbaru seperti Bisogno \& De Luca (2015), Humeedat (2018) dan Ranjbar \& Amanollahi (2018).

Dikembangkan awalnya oleh Altman pada tahun 1968 untuk memprediksi kebangkrutan, Altman's ZScore merupakan pilihan yang pantas bagi peneliti sebelum menggunakan pendekatan lain dan bagi mereka yang tidak ingin membatasi jumlah sampel. Z-Score juga tidak hanya digunakan pada perusahaan yang mengalami kebangkrutan saja (financial distress tahap ekstrim), tetapi juga pada tahapantahanpan lain yang lebih ringan (Nagar \& Sen, 2016).

Manajemen laba umumnya diasosiasikan dengan accruals earnings management (AM). Para manajer memiliki fleksibilitas untuk memilih beberapa alternatif dalam mencatat transaksi sekaligus memilih opsi-opsi yang ada sesuai standar akuntansi. Fleksibilitas ini digunakan oleh manajemen perusahaan untuk mengelola laba. Perilaku manajemen yang mendasari lahirnya manajemen laba adalah perilaku opportunistic dan efficient contracting. Dalam perilaku opportunistic, manajer memaksimalkan utilitasnya dalam menghadapai kontrak kompensasi dan hutang, serta political cost. Perilaku opportunistis ini direfleksikan dengan melakukan rekayasa keuangan dengan menerapkan income increasing atau income decreasing decretionary accrual. Sedangkan dalam efficient contracting, manajer meningkatkan keinformatifan laba dalam mengkomunikasikan informasi privat (Scott, 2006).

Manajemen laba dapat dilakukan dengan mengambil keuntungan dari efek pilihan akuntansi yang memberikan dasar bagi keputusan yang terbaik bagi perusahaan. Salah satu upaya yang dilakukan manajer yaitu mengganti atau mengubah suatu metode akuntansi tertentu dari sekian banyak metode yang dapat dipilih, yang tersedia dan diakui oleh prinsip akuntansi yang berterima umum (generally accepted accounting principles/GAAP). Hal ini berarti bahwa perusahaan yang mempraktikkan manajemen laba juga akan mengelola laba mereka dalam batas-batas prosedur akuntansi yang berlaku. Manajemen termotivasi untuk terlibat dalam praktik manajemen laba guna melaporkan pendapatan yang tinggi dan nilai-nilai ekonomi yang lebih besar dari perusahaan. Upaya manajemen untuk melaporkan pendapatan yang lebih tinggi guna memperlihatkan kinerja yang baik kepada para pemegang saham dan pemangku kepentingan lainnya dengan harapan mendapatkan imbal hasil berupa bonus. Selain itu, alasan lain bagi manajemen untuk melaporkan pendapatan yang lebih tinggi yaitu untuk mengurangi kemungkinan kegagalan pelunasan hutang perusahaan.

Manajemen laba merupakan salah satu faktor yang dapat mengurangi kredibilitas laporan keuangan, manajemen laba menambah bias dalam laporan keuangan dan dapat mengganggu pemakai laporan keuangan yang mempercayai angka laba hasil rekayasa tersebut sebagai angka laba tanpa 
rekayasa. Menurut Nagar \& Sen (2016), pola manajemen laba dapat dilakukan dengan berbagai cara. Taking a bath dilakukan pada saat reorganisasi termasuk pengangkatan CEO baru dengan melaporkan kerugian dalam jumlah besar, income minimization pada saat profitabilitas tinggi, income maximization pada saat laba menurun, dan income smoothing dengan cara meratakan laba untuk mengurangi fluktuasi laba yang terlalu besar.

Real earnings management (RM) merujuk pada aktivitas riil yang diambil perusahaan untuk mengatur laba dan cash flow (García et al. 2009). Bila manajer ingin meningkatkan laba, pengeluaran discretionary seperti riset, penjualan administrasi dan umum, perjalanan dan pemeliharaan dapat dikurangi. Cara lain yang dapat ditempuh adalah dengan mengatur tingkat produksi dan timing penjualan. Literatur mengenai RM tidaklah sebanyak AM, hal ini terkait masih terbatasnya penelitian yang mengangkat RM sebagai opsi lain dari manajemen laba. Cara terakhir yang dapat ditempuh manajer dalam mengelola laba pada saat financial distress adalah dengan melakukan classification shifting (CS). Manajer secara oportunistik akan menggeser biaya-biaya dari harga pokok dan biaya operasi ke dalam kategori income-decreasing special items atau income-decreasing discontinued operations (Fan et al. 2010). Hal ini dilakukan untuk meningkatkan laba operasi atau laba inti sehingga seolah-olah perusahaan masih dalam keadaan baikbaik saja. Tidak seperti halnya AM dan RM, CS tidak berpengaruh terhadap laba saat ini atau yang akan datang. Terlebih lagi, CS tidak terlalu diperhatikan oleh auditor maupun pemerintah karena tidak mempengaruhi bottom line (McVay, 2006).

Terdapat banyak literatur mengenai penggunaan accruals earnings management dalam perusahaan yang mengalami financial distress. Penelitianpenelitian jenis ini memfokuskan pada pelanggaran debt covenants (Dichev \& Skinner, 2002) dan (Jaggi \& Lee, 2002), kebangkrutan (Rosner, 2003) dan (García et al. 2009), mengalami kerugian beruntun (Callen et al. 2008). Zang (2012) menguji hubungan distress dengan AM menggunakan Altman's Z-Score sebagai proksinya. Jaggi \& Lee (2002) menemukan apabila distress bersifat sementara maka manajer mengelola laba secara oportunistik untuk menunjukkan kinerja yang lebih baik. Namun apabila distress bersifat ekstrim dan berkepanjangan, manajer akan melaporkan laba yang lebih konservatif guna memperoleh kemudahan dalam renegosiasi utang.
Pada perkembangan selanjutnya, penelitian mulai memasukkan strategi real earnings management (RM) sebagai tambahan dari accruals earnings management (AM). Pionir penelitian yang menonjol adalah García et al. (2009) yang menemukan bahwa empat tahun sebelum kebangkrutan perusahaan melakukan incomeincreasing AM dan manipulasi penjualan. Zang (2012) menemukan bahwa perusahaan yang mengalami financial distress menggunakan lebih banyak AM daripada RM. Penelitian terbaru yang paling mendekati penelitian ini adalah Nagar \& Sen (2016). Penelitiannya menemukan bahwa pada tahap awal financial distress, perusahaan akan melakukan RM melalui pemotongan biaya-biaya discretionary dan peningkatan produksi, serta classification shifting (CS) untuk meningkatkan profitabilitas dan likuiditas. Pada tahap-tahap yang lebih parah, perusahaan akan mengurangi produksi, melakukan income-increasing AM dan meningkatkan pengeluaran discretionary.

Dampak negatif dari accruals earnings management telah banyak dibuktikan dalam penelitian terdahulu, seperti dalam Janes (2003). Dampak yang paling utama adalah menurunnya kinerja perusahaan di masa depan. Dampak lain dapat berupa perubahan auditor, pelanggaran standar akuntansi dan pelanggaran perjanjian utang. Di sisi lain, dampak dari strategi manajemen laba melalui pemotongan biaya discretionary dan tingkat produksi belum menunjukkan konsistensi. Zang (2012) dan Leggett et al. (2009) menyimpulkan dampak negatif sedangkan Gunny (2010) dan Taylor \& Xu (2010) menyimpulkan dampak positif terhadap kinerja keuangan.

Penelitian mengenai classification shifting (CS) juga belum banyak dilakukan. Fan et al. (2010) menemukan bahwa CS lebih banyak dilakukan pada kuartal keempat dibandingkan tiga kuartal lainnya. Manajer cenderung melakukan strategi ini apabila neraca telah kembung (bloated) sebagai akibat AM yang diterapkan sebelumnya.

Penelitian yang mengaitkan financial distress dengan accruals earnings management masih menemukan hasil yang bervariasi. Bisogno \& De Luca (2015) menemukan bahwa perusahaan menjelang kebangkrutan di Italia cenderung melakukan income-increasing accruals earnings management melalui penggelembungan penjualan guna memperoleh pendanaan eksternal. Ranjbar \& Amanollahi (2018) menemukan bahwa tingkat 
financial distress mempengaruhi earnings management pada perusahaan yang terdaftar di Tehran Stock Exchange. Kedua penelitian tersebut menyimpulkan bahwa semakin tinggi tingkat financial distress maka semakin tinggi pula kecenderungan manajemen untuk melakukan manajemen laba. Penelitian oleh Agrawal et al. (2015) sebaliknya menemukan bahwa perusahaan yang memiliki tingkat distress yang lebih rendah justru memiliki insentif lebih tinggi untuk melakukan manajemen laba melalui discretionary accruals. Sedangkan Humeedat (2018), menemukan bahwa earnings management tidak berkaitan dengan financial distress pada perusahaan di Yordania.

Menurut Teori Akuntansi Positif dari Watts \& Zimmerman (1978), manajemen memiliki motivasi melakukan laba terkait financial distress terutama dapat dilihat dari aspek bonus plan hypothesis dan debt to equity (DER) hypothesis. Bonus plan hypothesis menyatakan manajer yang memperoleh bonus dari perusahaan akan cenderung memilih metode akuntansi yang memaksimalkan laba sehingga meningkatkan bonus yang diterima. Hal ini juga didukung oleh teori keagenan yang menyatakan bahwa manajer selaku agen dapat besikap oportunistik guna memaksimalkan kepentingannya sendiri meskipun harus mengorbankan kemakmuran pemegang saham selaku principal (Watts \& Zimmerman, 1990). Debt to equity (DER) hypothesis di sisi lain menyatakan bahwa semakin tinggi DER maka manajer akan semakin cenderung memilih metode akuntansi yang dapat meningkatkan laba guna menghindari kemungkinan pelanggaran terhadap perjanjian utang dan kemungkinan default (Salah, 2010).
Penelitian ini ditujukan untuk mengidentifikasi pilihan-pilihan strategi manajemen laba yang diambil manajemen pada berbagai tahapan financial distress, baik itu pada tahap awal, lanjut maupun akhir. Adapun strategi manajemen laba yang dikaji tidak hanya terbatas pada strategi akrual (accruals earnings management) yang umumnya banyak diteliti, namun juga mencakup strategi lain dalam mengatur laba seperti strategi riil (real earnings management) dan pergeseran klasifikasi laba rugi (classification shifting).

\section{METODE PENELITIAN}

Penelitian ini menggunakan sampel yang dikumpulkan melalui purposive sampling. Penelitian ini dilakukan pada seluruh perusahaan manufaktur yang terdaftar di BEI selama enam tahun dari 2012 sampai 2017 yang mengalami financial distress. Adapun jumlah perusahaan emiten BEI sektor manufaktur per 31 Desember 2017 adalah 147 perusahaan. Dari hasil seleksi didapatkan bahwa terdapat 43 perusahaan yang mengalami financial distress pada berbagai tahapan. BEI merupakan salah satu bursa terkuat di Asia selain China dan India, dan merupakan salah satu bursa emerging markets yang menjadi sasaran berbagai investor global. Sektor manufaktur di BEI dipilih karena merupakan sektor paling dominan secara kapitalisasi pasar dan jumlah emiten, serta proses bisnis yang lebih kompleks dibanding sektor lain. Penggunaan seluruh emiten manufaktur juga ditujukan untuk menjamin ukuran sampel yang memadai secara cross-sectional sehingga hasil regresi yang diperoleh lebih kredibel. Adapun rincian sampel yang digunakan dalam penelitian ini dapat dilihat pada Tabel 1.

\section{Tabel 1. Sampel dan Data Penelitian}

\begin{tabular}{lr}
\hline \multicolumn{1}{c}{ Keterangan } & Jumlah \\
\hline Perusahaan sektor manufaktur yang terdaftar di BEI per 31 Desember & 147 \\
2017 & 43 \\
Perusahaan yang mengalami financial distress selama periode penelitian & 6 \\
Jumlah periode pengamatan (tahun) & 258 \\
Jumlah data amatan (poin 2 dikalikan poin 3) &
\end{tabular}

Dalam menghitung accrual earnings management (AM), penelitian ini menggunakan model dari Kothari \& Leone (2005) karena telah memodifikasi dan memperbaiki kekurangan dari model perhitungan akrual sebelumnya yakni model
Jones (Jones, 1991) dan modified Jones (Dechow et al., 2010), dengan menambahkan nilai return on assets/ROA untuk mengontrol tingkat normal dari kondisi akrual. Model persamaan milik Kothari \& Leone (2005) adalah sebagai berikut: 
$\operatorname{Acc}_{t} / A_{t-1}=\alpha_{0}+\alpha_{1}\left(1 / A_{t-1}\right)+\beta_{1}\left(\Delta S_{t} / A_{t-1}\right)+\beta_{2}\left(P P E_{t}\right.$ $\left.A_{t-1}\right)+\beta_{3}\left(\operatorname{ROA}_{t}\right)+\varepsilon_{t} \ldots \ldots \ldots \ldots \ldots . . .(1)$

Adapun perhitungan dari masing-masing variabel dalam model di atas adalah sebagai berikut: Acc $_{\mathrm{t}}$ : Net Income - Cashflow From Operation $\Delta \mathrm{S}_{, \mathrm{t}}:$ Sales $_{t}-$ Sales $_{t-1}$

\section{ROA $_{t}:$ Net Income Total Assets}

PPE $_{\mathrm{t}}$ : Harga Perolehan Aktiva Tetap - Depresiasi Aktiva Tetap.

Keterangan:

Acc $_{\mathrm{t}}$ : Ukuran mengenai total akrual perusahaan pada tahun $\mathrm{t}$

$\Delta \mathrm{S}_{\mathrm{t}}$ : Perubahan besarnya penjualan perusahaan pada tahun $\mathrm{t}$

$\mathrm{PPE}_{\mathrm{t}}$ : Nilai bersih total aset tetap yang dimiliki perusahaan pada tahun $\mathrm{t}$

$\mathrm{ROA}_{t}$ : Pengukuran kinerja yang berasal dari tingkat pengembalian aset

$\mathrm{A}_{\mathrm{t}-1}$ : Jumlah nilai total aset perusahaan pada periode sebelumnya

Menurut Kothari \& Leone (2005), seluruh variabel di atas dibagi dengan $\operatorname{ASSETS}_{i, t-1}$ untuk mencegah terjadinya heteroskedastisitas pada nilai residual yang akan diperoleh. Level normal dari akrual dihitung dengan menggunakan persamaan untuk industri. Kemudian level normal tersebut dikurangkan dari level aktual untuk mendapatkan akrual abnormal. Nilai residual inilah yang akan dipakai sebagai ukuran accrual earnings management (AM) (Dechow et al. 2010). Real earnings management (RM) dalam penelitian ini mengadopsi model yang dikembangkan oleh Gunny (2010). Adapun perhitungan dari masing-masing komponen RM yaitu pengeluaran riset, pengeluaran penjualan administrasi dan umum, serta tingkat produksi adalah sebagai berikut:

$\mathrm{RDt} / \mathrm{At}-1=\alpha 0+\alpha 1(1 / \mathrm{At}-1)+\beta 1(\mathrm{MVt})+$ $\beta 2(\mathrm{Qt})+\beta 3(\mathrm{INTt} / \mathrm{At}-1)+\beta 4(\mathrm{RDt}-$ $1 / \mathrm{At}-1)+\varepsilon \mathrm{t}$.

SGAt/At- $1=\alpha 0+\alpha 1(1 /$ At -1$)+\beta 1(\mathrm{MVt})+$ $\beta 2(\mathrm{Qt})+\beta 3(\mathrm{INTt} / \mathrm{At}-1)+\beta 4(\Delta \mathrm{St} /$ $\mathrm{At}-1)+\beta 5(\Delta \mathrm{St} / \mathrm{At}-1 * \mathrm{DD})+$ Et...................................(3)

PRODt/At-1 $=\alpha 0+\alpha 1(1 /$ At -1$)+\beta 1(\mathrm{MVt})+$ $\beta 2(\mathrm{Qt})+\beta 3(\mathrm{St} / \mathrm{At}-1)+\beta 4(\Delta \mathrm{St} / \mathrm{At}-$ $1)+\beta 5(\Delta \mathrm{St}-1 / \mathrm{At}-1)+\varepsilon \mathrm{t} \ldots \ldots . .(4)$
Keterangan:

$\begin{array}{lll}\mathrm{RD} & : & \text { biaya R\&D } \\ \mathrm{A} & : & \text { Total assets } \\ \mathrm{MV} & : & \text { Log dari nilai pasar ekuitas } \\ \mathrm{Q} & : & \text { Tobin } \mathrm{Q} \\ \mathrm{INT} & : & \text { Dana Internal } \\ \mathrm{SGA} & : & \text { biaya penjualan administrasi dan umum } \\ \mathrm{S} & : & \text { Penjualan } \\ \mathrm{DD} & : & \text { dummy, } 1 \text { bila penjualan turun antara } t-1 \\ & & \text { and } t, 0 \text { jika sebaliknya } \\ \text { PROD } & \begin{array}{l}\text { Harga pokok penjualan }+ \text { perubahan } \\ \text { persediaan. }\end{array}\end{array}$

Level normal dari masing-masing komponen RM dihitung dengan menggunakan persamaan untuk industri. Kemudian level normal tersebut dikurangkan dari level aktual untuk mendapatkan level abnormal. Classification Shifting (CS) dihitung dari nilai core earnings dalam model McVay (2006) sebagai berikut:
$\mathrm{CEt} / \mathrm{St}=\beta 0+\beta 1(\mathrm{CEt}-1 / \mathrm{St}-1)+\beta 2(\mathrm{ATOt})+\beta 3$ $($ Acct $-1 / \mathrm{St})+\beta 3($ Acct $/ \mathrm{St})+\beta 4(\Delta \mathrm{St} /$ St-1 $)+\beta 5($ Neg_ $\Delta \mathrm{St})+\varepsilon \mathrm{t}$.

Keterangan:

CE (core earnings) : Penjualan - Harga Pokok

$\mathrm{S}$

ATO - Biaya SGA

Acc : Penjualan

$\Delta \mathrm{St}$

Neg_ÄSt

: Assets Turnover

: Totalaccruals

: St - St-1

: ÄSt/St-1, 1 jika ÄSt/St-1 bernilai negatif, 0 jika tidak.

Seperti halnya RM, level normal dari CS dihitung dengan menggunakan persamaan untuk industri. Kemudian level normal tersebut dikurangkan dari level aktual untuk mendapatkan level abnormal. Altman's Z-Score digunakan dalam penelitian ini untuk mengukur financial distress. Ukuran ini telah terbukti memiliki akurasi tinggi (sampai 90 persen) untuk memprediksi kebangkrutan dan financial distress pada tahap yang lebih ringan. Altman's Z Score juga memungkinkan diperolehnya jumlah sampel yang memadai guna hasil analisis yang lebih akurat (Nagar \& Sen, 2016). Perhitungan Altman's Z-Score didasarkan pada tingkat likuiditas, usia, profitabilitas inti, solvensi dan efisiensi. Perusahaan dikatakan mengalami financial distress apabila nilai 
Z-Scorenya kurang dari 1,81 pada tahun t-1. Adapun formula dari Altman's Z-Score adalah sebagai berikut:

$$
\begin{aligned}
\mathrm{Z}= & 1,2(\mathrm{WC} / \mathrm{TA})+1,4(\mathrm{RE} / \mathrm{TA})+3,3(\mathrm{EBIT} / \mathrm{TA}) \\
& +0,6(\mathrm{MVE} / \mathrm{TL})+1,0(\mathrm{~S} / \mathrm{TA}) \ldots \ldots .(6)
\end{aligned}
$$

Dimana:

$$
\begin{array}{ll}
\mathrm{Z} & =\text { Z-Score } \\
\mathrm{WC} & =\text { Modal Kerja } \\
\mathrm{TA} & =\text { Total Assets } \\
\mathrm{RE} & =\text { Laba Ditahan } \\
\mathrm{EBIT} & =\text { Laba sebelum bunga dan pajak } \\
\mathrm{MVE} & =\text { Nilai Pasar Ekuitas } \\
\mathrm{TL} & =\text { TotalLiabilities } \\
\mathrm{S} & =\text { Penjualan. }
\end{array}
$$

Financial distress diberi nilai 1 jika Z-Scorenya kurang dari 1,81 pada tahun t-1, dan sebaliknya 0 . Karena penelitian ini berfokus pada tahapan-tahapan financial distress, maka nilai Z-Score di atas dikembangkan lagi menjadi distress tahap awal (D1) sampai tahap ekstrim (D5). D1 = 1 jika perusahaan distress pada tahun $t-1$ namun tidak pada tahun $t-2$ sampai $t-5$, sebaliknya $0, \mathrm{D} 2=1$ jika perusahaan distress pada tahun $t-1$ dan $t-2$ namun tidak pada tahun $t$-3 sampai $t-5$, sebaliknya 0 , dan seterusnya. Perusahaan dikatakan mengalami financial distress tahap awal pada D1 dan D2, tahap lanjut pada D3 dan D4, serta tahap ekstrim pada D5.Setelah dihitung masing-masing variabel terikat (Y) yaitu AM, RM (RD, SGA, PROD) dan CS, variabel bebas (X) yakni D1, D2, D3, D4, D5, maka model-model regresi majemuk disusun untuk menjawab masalah penelitian. Adapun model-model regresi tersebut adalah sebagai berikut:

$$
\begin{aligned}
& \mathrm{AM}=\alpha+\beta_{1} \mathrm{D}_{1}+\beta_{2} \mathrm{D}_{2}+\beta_{3} \mathrm{D}_{3}+\beta_{4} \mathrm{D}_{4}+\beta_{5} \\
& \mathrm{D}_{5}+\mathrm{t} . \\
& R D=\alpha+\beta_{1} D_{1}+\beta_{2} D_{2}+\beta_{3} D_{3}+\beta_{4} D_{4}+\beta_{5} \\
& \mathrm{D}_{5}+\varepsilon \mathrm{t} \text {. } \\
& \mathrm{SGA}=\alpha+\beta_{1} \mathrm{D}_{1}+\beta_{2} \mathrm{D}_{2}+\beta_{3} \mathrm{D}_{3}+\beta_{4} \mathrm{D}_{4}+\beta_{5} \\
& \mathrm{D}_{5}+\varepsilon \mathrm{t} \ldots \ldots \ldots \ldots \ldots \ldots \ldots \ldots \ldots \ldots . . . \ldots(9) \\
& \text { PROD }=\alpha+\beta_{1} D_{1}+\beta_{2} D_{2}+\beta_{3} D_{3}+\beta_{4} D_{4}+\beta_{5} \\
& \mathrm{D}_{5}+\varepsilon \mathrm{t} \ldots \ldots \ldots \ldots \ldots \ldots \ldots \ldots \ldots \ldots \ldots \ldots(10) \\
& \mathrm{CS}=\alpha+\beta_{1} \mathrm{D}_{1}+\beta_{2} \mathrm{D}_{2}+\beta_{3} \mathrm{D}_{3}+\beta_{4} \mathrm{D}_{4}+\beta_{5} \\
& \mathrm{D}_{5}+\varepsilon \text { t.............................(11) }
\end{aligned}
$$

Dari nilai $p$-value masing-masing variabel D1 sampai D5 pada persamaan-persamaan di atas, maka akan dapat diidentifikasi strategi manajemen laba mana yang diterapkan pada masing-masing tahapan financial distress. Rancangan penelitian ini dapat digambarkan seperti pada Gambar 1.

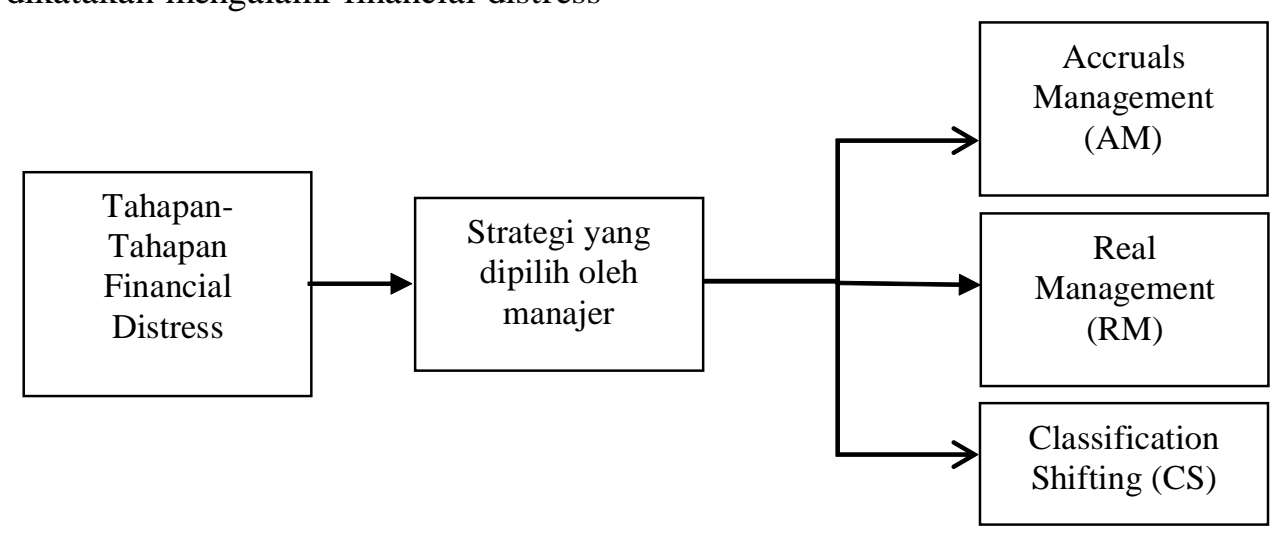

Gambar 1. Desain Penelitian

Sumber: Data diolah, 2018

\section{HASIL DAN PEMBAHASAN}

Perhitungan nilai Altman's Z-Score seperti diformulasikan di atas dilakukan terhadap seluruh perusahaan manufaktur yang terdaftar di BEI per 31 Desember 2017 guna mengidentifikasi perusahaan-perusahaan mana yang mengalami financial distress dan tidak. Berdasarkan nilai Altman's Z-Score tersebut kemudian dipilah dengan menggunakan nilai batas 1,81 dimana nilai Altman's Z-Score di atas 1,81 menunjukkan perusahaan yang mengalami distress dan di atas 1,81 menunjukkan perusaahaan yang tidak mengalami financial distress. Tahapan-tahapan financial distress diperoleh dari data time-series selama lima tahun ke belakang kondisi financial distress suatu perusahaan. Label D1 menunjukkan kondisi financial distress tahap awal hingga D5 menunjukkan kondisi financial distress ekstrim. Setelah dilakukan perhitungan, didapat 43 perusahaan manufaktur yang mengalami financial distress dengan berbagai tingkat tahapan distress seperti yang diuraikan pada Tabel 2. 
Tabel 2. Berbagai Tahapan Financial Distress Perusahaan Manufaktur

\begin{tabular}{lcc}
\hline Tahapan & \multicolumn{3}{c}{ Jumlah Perusahaan } \\
Distress & D1 & 10 \\
\hline Awal & D2 & 7 \\
& D3 & 0 \\
Lanjut & D4 & 3 \\
& D5 & 23 \\
Ekstrim & & 43 \\
\hline Total Sampel & &
\end{tabular}

Sumber: Data diolah, 2018

Tabel 2 di atas dapat dilihat bahwa terdapat 43 perusahaan dari total 147 perusahaan manufaktur yang terdaftar di BEI yang mengalami financial distress (25,3 persen). Dari 43 perusahaan tersebut, 10 di antaranya mengalami distress tahun pertama, 7 distress tahun kedua, 3 distress tahun keempat dan paling banyak adalah 23 perusahaan distress tahun kelima (ekstrim). Tahap berikutnya dilakukan perhitungan terhadap nilai-nilai variabel dependen yang digunakan dalam model-model penelitian, yakni strategi accuals management (AM), selling general administrative expenses (SGA), over production (PROD) dan classification shifting (CS). Perhitungan dari masing-masing variabel ini dilakukan dengan mengurangkan hasil normal untuk industri dari nilai aktual untuk mendapatkan level abnormalnya. Adapun perhitungan level normal dilakukan dengan regresi majemuk dengan mengadopsi model Kothari \& Leone (2005) untuk AM, model Gunny (2010) untuk SGA dan overproduction, serta model McVay (2006) untuk CS. Dari regresi yang dilakukan, maka didapat persamaan-persamaan regresi untuk masing-masing variabel sebagai berikut:

$\mathrm{AM}$ :

$$
\begin{aligned}
\mathrm{Acc}_{\mathrm{t}} / \mathrm{A}_{\mathrm{t}-1=}= & -0,112+0,051\left(1 / \mathrm{A}_{\mathrm{t}-1}\right)-0,236\left(\Delta \mathrm{S}_{\mathrm{t}} /\right. \\
& \left.\mathrm{A}_{\mathrm{t}-1}\right)+0,082\left(\mathrm{PPE}_{\mathrm{t}} / \mathrm{A}_{\mathrm{t}-1}\right)+ \\
& 1,013\left(\mathrm{ROA}_{\mathrm{t}}\right)+\varepsilon_{\mathrm{t}}
\end{aligned}
$$

SGA :

$$
\begin{aligned}
\text { SGAt/At- }= & -0,035+0,002(1 / \text { At }-1)+0,011(\mathrm{MVt}) \\
& +0,025(\mathrm{Qt})+0,013(\mathrm{INTt} / \mathrm{At}-1)+ \\
& 0,207(\Delta \mathrm{St} / \mathrm{At}-1)-0,287(\Delta \mathrm{St} / \mathrm{At}- \\
& 1 * \mathrm{DD})+\mathrm{t} \\
\text { PROD : } & \\
\text { PRODt/At- }= & 0,165-0,005(1 / \mathrm{At}-1)-0,036(\mathrm{MVt}) \\
& +0,031(\mathrm{Qt})+0,902(\mathrm{St} / \mathrm{At}-1)- \\
& 0,046(\Delta \mathrm{St} / \mathrm{At}-1)-0,071(\Delta \mathrm{St}-1 / \text { At- } \\
& 1)+[\mathrm{t}
\end{aligned}
$$

CS:

$\mathrm{CEt} / \mathrm{St}=0,081+0,136(\mathrm{CEt}-1 / \mathrm{St}-1)-0,041$

$$
(\text { ATOt })+0,108(\text { Acct- } 1 / \mathrm{St})-0,091
$$

$$
\begin{aligned}
& (\text { Acct } / \mathrm{St})+0,004(\Delta \mathrm{St} / \mathrm{St}-1)- \\
& 0,046\left(\mathrm{Neg} \_\Delta \mathrm{St}\right)+[\mathrm{t}
\end{aligned}
$$

Regresi untuk strategi biaya riset dan pengembangan (RD) tidak dapat dilakukan dikarenakan tidak tersedianya data biaya riset dan pengembangan pada laporan keuangan perusahaanperusahaan yang diteliti. Hal ini dapat diakibatkan karena memang perusahaan tidak mengeluarkan biaya khusus untuk riset dan pengembangan atau biaya untuk hal tersebut tidak signifikan sehingga tidak dicantumkan secara terpisah pada komponen laporan keuangan. Level normal masing-masing perusahaan untuk variabel AM, SGA, PROD dan CS dihitung dengan menggunakan persamaanpersamaan regresi yang diperoleh di atas. Kemudian nilai aktual dari masing-masing perusahaan dikurangkan dengan level normal guna menghasilkan level abnormal. Level abnormal inilah yang nantinya akan digunakan dalam model-model regresi guna mengidentifkasi pilihan strategi manajemen laba pada berbagai tahapan financial distress.

Pengujian model-model regresi untuk mengidentifikasi pilihan strategi manajemen laba pada berbagai tahapan financial distress dilakukan dengan menggunakan level-level abnormal dari strategi manajemen laba (AM, SGA, PROD dan CS) yang dihitung sebelumnya sebagai variabel dependen (Y) dan tahapan financial distress (D1, D2,D3, D4 dan D5) sebagai variabel independen (X). Setelah dilakukan pengolahan dengan SPSS, maka didapatkan persamaan-persamaan regresi sebagai berikut:

$\mathrm{AM}=0,162-0,071 \mathrm{D} 2-0,065 \mathrm{D} 4-0,096 \mathrm{D} 5+[\mathrm{t}$ SGA $=0,089-0,018 \mathrm{D} 2-0,063 \mathrm{D} 4-0,023 \mathrm{D} 5+[\mathrm{t}$ $\mathrm{PROD}=0,090-0,074 \mathrm{D} 2-0,019 \mathrm{D} 4-0,034 \mathrm{D} 5+[\mathrm{t}$ CS $=0,090-0,074 \mathrm{D} 2-0,019 \mathrm{D} 4-0,030 \mathrm{D} 5+[\mathrm{t}$

Pemilihan strategi manajemen laba pada masingmasing tahapan financial distress dapat dilihat dari p-value dari masing-masing koefisien (beta) pada keempat persamaan regresi di atas. Rincian koefisien beta beserta p-value untuk keempat persamaan 


\section{Tabel 3. Koefisien Beta dan p-value Model-Model Regresi Strategi Manajemen Laba}

\begin{tabular}{lrlrcrrrr}
\hline Tahapan & \multicolumn{2}{c}{ AM } & \multicolumn{2}{c}{ SGA } & \multicolumn{2}{c}{ PROD } & \multicolumn{2}{c}{ CS } \\
Distress & Beta & p-value & Beta & p-value & Beta & p-value & Beta & p-value \\
\hline Awal & $-0,071$ & 0,118 & $-0,018$ & 0,511 & $-0,074$ & $0,022^{*}$ & $-0,074$ & $0,025^{*}$ \\
Lanjut & $-0,065$ & 0,275 & $-0,063$ & $0,083^{* *}$ & $-0,019$ & 0,648 & $-0,019$ & 0,654 \\
Ekstrim & $-0,096$ & $0,007^{*}$ & $-0,023$ & 0,260 & $-0,034$ & 0,159 & $-0,030$ & 0,220
\end{tabular}

Sumber: Data diolah, 2018

Tabel 3 menunjukkan bahwa saat distress awal terdapat signifikansi pada alpha 5 persen untuk dua strategi sekaligus yaitu overproduction dan classification shifting dengan beta masing-masing lebih kecil dari nol. Hal ini menunjukkan bahwa pada tahapan ini perusahaan manufaktur cenderung melakukan real earnings management melalui penurunan output produksi dan melakukan classification shifting yaitu mengurangi core earnings dengan menurunkan laba operasional dan menggesernya ke bagian bawah laporan laba-rugi. Pada tahapan distress lanjutan, perusahaan melakukan pengurangan biaya-biaya selling, general \& administrative (SGA) seperti yang ditunjukkan oleh signifikansi pada alpha 10 persen dan beta lebih kecil dari nol saat distress lanjut pada model SGA. Pada tahap ekstrim, perusahaan melakukan accrual earnnings management melalui teknik income-decreasing (penurunan laba) seperti yang ditunjukkan oleh signifikansi pada alpha 5 persen beta lebih kecil dari nol saat distress ekstrim pada model AM.

Strategi manajemen laba yang diambil perusahaan manufaktur di Indonesia pada tahap awal financial distress adalah dengan melakukan penurunan produksi dan classification shifting dengan mengurangi laba operasional (core earnings). Hasil penelitian ini berbeda dari hasil penelitian dari Nagar (2016) yang menemukan bahwa perusahaan cenderung menurunkan beban sales, general and administrative (SGA) dan melakukan classification shifting dengan meningkatkan laba operasional pada periode-periode awal financial distress.

Penurunan produksi dapat terjadi sebagai akibat menurunnya permintaan konsumen yang sering menandai tahap-tahap awal financial distress. Keterlambatan mengantisipasi tren permintaan ini mengakibatkan perusahaan harus menghadapi penumpukan persediaan sehingga menekan produksi. Selain itu, penurunan jumlah produksi juga dapat merupakan usaha manajemen untuk menata ulang proses produksi untuk mengejar efisiensi, fokus pada produk inti atau menyesuaikan dengan permintaan pasar. Manajemen akan mereview lini produk apa saja yang paling menguntungkan untuk dipertahankan dan lini produk apa yang harus dihentikan karena kurang menguntungkan.

Terjadinya classification shifting melalui mengurangan core earnings dapat diakibatkan oleh penurunan produksi. Pada tahap-tahap awal penurunan produksi, penurunan output tidak dapat langsung diikuti dengan penurunan kapasitas produksi sehingga biaya-biaya tetap produksi masih belum berkurang. Hal ini mengakibatkan cost of sales yang relatif tinggi dibanding sebelum terjadinya penurunan produksi. Penyebab kedua adalah adanya kemungkinan perilaku oportunistik manajemen yang memanfaatkan kondisi financial distress dengan melakukan big bath strategy. Strategi ini dilakukan terutama pada saat distress temporer dengan cara menurunkan jumlah produksi dan penjualan berikut dengan core earnings serendah mungkin dengan harapan pada saat perusahaan mengalami turnaround atau kondisi membaik, manajemen dapat dengan mudah mencapai target peningkatan kinerja dan bonus. Penurunan core earnings dapat juga dilakukan dengan mereklasifikasi beban-beban di luar usaha menjadi beban usaha. Perilaku oportunistik ini sejalan dengan bonus plan hypothesis dan teori keagenan dimana manajer berusaha memanfaatkan keadaan guna memaksimalkan keuntungan pribadi (Watts \& Zimmerman, 1990).

Dapat dilihat pada tahap awal financial distress tidak terjadi manajemen laba melalui accruals management dan pengurangan biaya-biaya selling, general \& administrative (SGA) karena distress dilihat hanya bersifat temporer sehingga langkahlangkah tersebut dipandang tidak perlu. Penyebab lainnya adalah biaya-biaya SGA cenderung bersifat relatif konstan dari waktu ke waktu terlepas dari fluktuasi bisnis. Pada tahapan distress lanjutan, perusahaan mulai melakukan pengurangan biayabiaya selling, general and administrative (SGA). 
Hasil penelitian ini berbeda dari hasil penelitian dari Nagar \& Sen (2016) yang menemukan bahwa pada tahap lanjuatan financial distress perusahaan cenderung menurunkan jumlah produksi, meningkatkan beban sales, general and administrative (SGA) dan melakukan incomeincreasing accruals management. Jika financial distress berkelanjutan dalam waktu yang cukup lama, perusahaan dapat mengalami penurunan yang tajam dalam profitabilitas dan likuiditas. Perusahaan mau tak mau harus mengurangi biaya-biaya diskresionari seperti biaya-biaya yang tegolong biaya SGA. Hal ini merupakan tindakan yang rasional sebagai respons terhadap penurunan penjualan dan produksi yang berkepanjangan. Pengurangan biaya SGA ini juga membantu meningkatkan profitabilitas jangka pendek, di samping menghemat cash flow yang berharga.

Terlihat pada tahap lanjutan ini perusahaan tidak lagi melakukan penurunan produksi dan classification shifting seperti pada tahap-tahap awal. Perusahaan kemungkinan telah menemukan tingkat output yang optimal sehingga tidak melakukan perubahan lagi. Classification shifting komponenkomponen laba rugi juga kemungkinan tidak lagi memberikan dampak yang signifikan pada tahap ini, di samping mulai terbatasnya opsi-opsi untuk itu. Perusahaan pada tahap ini juga kemungkinan tidak terlalu memperhatikan tren core earnings lagi tapi lebih pada bottom line earnings. Accruals management terutama yang bersifat incomeincreasing juga tidak terjadi pada tahap ini karena kemungkinan perusahaan melihat opsi ini tidak memberikan efek nyata bagi peningkatan kinerja perusahaan dan sudah menipisnya harapan untuk turnoround. Accruals management juga tidak berdampak apa-apa dalam meningkatkan likuiditas perusahaan. Hasil ini tidak mendukung debt to equity hypothesis dimana seharusnya perusahaan pada tahap ini berusaha menghindari pelanggaran perjanjian utang dan gagal bayar (Watts \& Zimmerman, 1990). Manajer juga tidak menunjukkan perilaku oportunistik dalam tahap ini.

Pada distress tahap ekstrim, perusahaan akan cenderung melakukan accruals management melalui teknik income-decreasing (penurunan laba). Hasil penelitian ini sejalan dengan hasil penelitian dari Nagar \& Sen (2016). Perusahaan dalam keadaan mendekati kebangkrutan akan cenderung bersikap lebih konservatif dengan menurunkan laba guna mendapatkan persyaratan yang lebih ringan dari kreditur (Jaggi \& Lee, 2002). Perilaku konservatif pada perusahaan yang menuju kebangkrutan atau telah melanggar perjanjian utang (debt covenant) seringkali dilandasi motif big bath oleh manajemen yang baru atau opini audit dengan pengecualian (qualified opinion) (Charitou et al., 2007). Hasil ini kembali menunjukkan perilaku oportunistik manajemen baru sesuai dengan bonus plan hypothesis dan teori keagenan.

Pada tahap ekstrim distress, perusahaan tidak lagi berusaha meningkatkan kinerja masa depan maupun profitabilitas baik melalui accruals management (AM) maupun real earnigs management (RM). Dengan kebangkrutan, likuidasi, atau restrukturisasi telah menjadi hampir pasti, manajemen akan berusaha mendapatkan manfaat atau posisi tawar terbaik dalam kondisi-kondisi tersebut. Cara yang umum dipakai adalah dengan melakukan income-decreasing accruals management. Penggunaan income-decreasing accruals management pada tahap ini tidak mendukung hasil penelitian-penelitian sebelumnya. Terlihat secara keseluruhan perusahaan manufaktur tidak terlalu mengandalkan akrual dalam memanipulasi laba saat dalam keadaan financial distress. Akrual hanya dimanfaatkan dalam kasus ekstrim distress sebagai upaya terakhir untuk restrukturisasi utang dan kepentingan manajemen baru. Literatur sebelumnya juga menemukan bukti terjadinya peningkatan biaya SGA pada distress tahap ekstrim sebagai bentuk perilaku oportunistik manajemen untuk memanfaatkan keadaan. Namun, penelitian ini tidak melihat gejala seperti demikian.

Penelitian ini telah memberikan bukti empiris mengenai pilihan strategi yang tersedia bagi manajemen pada saat perusahaan mengalami financial distress. Tidak hanya berfokus pada strategi akrual saja, penelitian ini juga memperhitungkan seluruh strategy-mix yang tersedia yang meliputi accruals management, real earnings management dan classification shifting. Penelitian sejenis ini relatif baru di Indonesia. Penelitian ini diharapkan dapat menginspirasi penelitian serupa di masa depan dengan mengambil data set yang lebih komprehensif, baik dari segi periode yang lebih panjang maupun lintas industri yang lebih luas.

Penelitian ini juga memberikan perspektif baru pada pilihan strategi manajemen laba pada berbagai tahapan financial distress dengan situasi dan karakternya masing-masing. Tahapan yang berbeda memiliki pengaruh yang berbeda-beda terhadap keputusan manajemen. Dengan mengidentifikasi 
strategi yang dipilih pada berbagai tahapan, kita dapat mempertajam pemahaman mengenai perilaku manajemen seta konsekuensinya bagi perusahaan.

Hasil penelitian juga dapat memberi manajemen pilihan strategi atau kombinasi beberapa strategi ketika menghadapi financial distress dengan mengamati praktik manajemen laba yang umum dilakukan pelaku industri. Terdapat banyak aspek yang membedakan perilaku manajemen dalam menghadapi financial distress jika dibandingkan dengan di negara lain. Penelitian ini memberikan gambaran nyata praktik manajemen laba pada perusahaan yng mengalami financial distress di Indonesia. Para investor, kreditor serta stakeholder lain perusahaan dapat lebih memahami kondisi yang melatarbelakangi informasi keuangan yang diterbitkan perusahaan. Penelitian ini melatih pengguna laporan keuangan dalam mengidentifikasi perilaku manajemen laba yang dilakukan perusahaan pada berbagai tahapan financial distress. Pemahaman yang lebih dalam mengenai apa yang tersirat, bukan sebatas yang tersurat, dalam laporan keuangan akan menghindarkan kesalahan dalam pengambilan keputusan.

\section{SIMPULAN}

Berdasarkan pembahasan sebelumnya dapat disimpulkan bahwa strategi manajemen laba yang diambil perusahaan pada tahap awal financial distress adalah dengan penurunan produksi dan classification shifting dengan mengurangi laba operasional. Strategi manajemen laba yang diambil perusahaan pada tahap lanjutan financial distress adalah dengan pengurangan biaya-biaya selling, general \& administrative (SGA). Strategi manajemen laba yang diambil perusahaan pada tahap ekstrim financial distress adalah dengan melakukan accruals management melalui teknik income-decreasing (penurunan laba).

Terdapat dua saran utama yang diperoleh dari hasil penelitian ini yaitu penelitian ini belum dilakukan dengan komprehensif karena hanya menggunakan pengamatan beberapa tahun. Penelitian selanjutnya perlu menggunakan periode pengamatan yang lebih panjang guna mendapatkan hasil yang lebih andal. Industri yang berbeda memiliki karakteristik yang berbeda pula. Penelitian serupa di masa datang dapat mengambil industri lain guna melihat konsistensi hasil atau perbedaan yang timbul antar industri beserta implikasinya.

\section{REFERENSI}

Agrawal, K., Chatterjee, C., Agrawal, K., \& Chatterjee, C. (2015). Earnings Management and Financial Distress: Evidence from India. Global Business Review, 16(5_suppl), 140S-154S. Retrieved from https://econpapers.repec.org/ article/saeglobus/v_3a16_3ay_3a2015_3ai_ 3a5_5fsuppl_3ap_3a140s-154s.htm

Bisogno, M., \& De Luca, R. (2015). Financial Distress and Earnings Manipulation: Evidence from Italian SMEs. Journal of Accounting and Finance, 4(1), 42-51. Retrieved from http://www. bioinfopublication.org/jouarchive.php?opt=\& jouid=BPJ0000233

Callen, J. L., Robb, S. W. G., \& Segal, D. (2008). Revenue manipulation and restatements by loss firms. Auditing: A Journal of Practice \& Theory, 27(2), 1-29. https://doi.org/10.2308/ aud.2008.27.2.1

Charitou, A., Lambertides, N., \& Trigeorgis, L. (2007). Earnings Behaviour of Financially Distressed Firms: The Role of Institutional Ownership. Abacus, 43(3), 271-296. https://doi.org/10.1111/ j.1467-6281.2007.00230.x

Dechow, P. M., Schrand, C. M., \& Collins, E. (2010). Earnings Quality. The Research Foundation of CFA Institute.

Dewi, N. M. S. S., \& Latrini, M. Y. (2016). Pengaruh Cash Holding, Profitabilitas dan Reputasi Auditor Pada Perataan Laba. E-Jurnal Akuntansi Universitas Udayana, Vol. 15(3), 2378-2408.

Dichev, I. D., \& Skinner, D. J. (2002). Large-Sample Evidence on the Debt Covenant Hypothesis. Journal of Accounting Research, 40(4), 10911123. https://doi.org/10.1111/1475-679X.00083

Fan, Y., Barua, A., Cready, W. M., \& Thomas, W. B. (2010). Managing Earnings Using Classification Shifting: Evidence from Quarterly Special Items. The Accounting Review, 85(4), 1303-1323. https://doi.org/10.2308/accr.2010.85.4.1303

García Lara, J. M., Osma, B. G. \& Neophytou, E. (2009). Earnings quality in ex post failed firms. Accounting and Business Research, 39(2), 119-138. https://doi.org/10.1080/00014788.2009.9663353

Gunny, K. A. (2010). The relation between earnings management using real activities manipulation and future performance: Evidence from meeting earnings benchmarks. Contemporary Accounting Research, 27(3), 855-888. https://doi.org/10.1111/ j.1911-3846.2010.01029.x 
Humeedat, M. M. (2018). Earnings Management to Avoid Financial Distress and Improve Profitability: Evidence from Jordan. International Business Research, 11(2), 222. https://doi.org/10.5539/ ibr.v11n2p222

Jaggi, B., \& Lee, P. (2002). Earnings Management Response to Debt Covenant Violations and Debt Restructuring. Journal of Accounting, Auditing \& Finance, 17(4), 295-324. https:// doi.org/10.1177/0148558X0201700402

Janes, T. D. (2003). Accruals, Financial Distress, and Debt Covenants. University of Michigan Business School.

Jones, J. J. (1991). Earnings Management During Import Relief Investigations. Journal of Accounting Research, 29(2), 193. https://doi. org/10.2307/2491047

Kothari, S. P., \& Leone, A. J. (2005). Performance Matched Discretionary Accrual Measures. Journal of Accounting and Economics, 39(1), 163-197.

Leggett, D. M., Parsons, L. M., Reitenga, A. L. (2009). Real Activities Manipulation and Subsequent Accounting Performance.

McVay, S. E. (2006). Classification Shifting/ : An Examination of Core Earnings and Special Items (Vol. 81).

Nagar, \& Sen, K. (2016). Earnings Management Strategies during Financial Distress (No. No. 2016-02-03).

Ranjbar, S., \& Amanollahi, G. F. (2018). The Effect of Financial Distress on Earnings Management and Unpredicted Net Earnings in Companies Listed on Tehran Stock Exchange. Management Science Letters, 8(9), 933-938. https://doi.org/ $10.5267 /$ j.msl.2018.6.015

Rosner, R. L. (2003). Earnings Manipulation in Failing
Firms. Contemporary Accounting Research, 20(2), 361-408. https://doi.org/10.1506/8EVN9KRB-3AE4-EE81

Salah, A. (2010). Earnings Management in the Years Following The Integrated Corporate Income Tax Within Dutch Housing Associations. Erasmus University Rotterdam.

Scott, W. R. (2006). Financial Accounting Theory (Fourth). Toronto: Prentice Hall International Inc.

Simbolon, H. A. (2015). Toshiba Accounting Scandal: Runtuhnya Etika Bangsa Jepang Yang Sangat Diagungkan Itu | Akuntansi Terapan. Retrieved July 1, 2019, from Akuntansi Terapan website: https://akuntansiterapan.com/2015/07/22/ toshiba-accounting-scandal-runtuhnya-etikabangsa-jepang-yang-sangat-diagungkan-itu/

Taylor, G. K., \& Xu, R. Z. (2010). Consequences of real earnings management on subsequent operating performance. Research in Accounting Regulation, 22(2), 128-132. https:/ /doi.org/10.1016/J.RACREG.2010.07.008

Watts, R. L., \& Zimmerman, J. L. (1978). Towards a Positive Theory of the Determination of Accounting Standards. The Accounting Review, 53, 112-134. Retrieved from http://www. scirp.org/(S(351jmbntvnsjt1aadkposzje))/ reference/ReferencesPapers.aspx? Reference ID $=1337749$

Watts, R. L., \& Zimmerman, J. L. (1990). Positive Accounting Theory/ : A Ten Year Perspective. The Accounting Review, (May 1989), 131-156.

Zang, A. Y. (2012). Evidence on the Trade-Off between Real Activities Manipulation and Accrual-Based Earnings Management. The Accounting Review, 87(2), 675-703. https:// doi.org/10.2308/accr-10196 